\title{
BIOSORPTION OF CATIONIC DYES FROM AQUEOUS SOLUTION BY WATER HYACINTH ROOTS
}

\author{
Ö. SALTABAŞ ${ }^{1 *}$ \\ M. TEKER ${ }^{2}$ \\ Z. KONUK ${ }^{2}$
}

Received: 22/08/11

Accepted: 05/10/11

\author{
${ }^{1}$ Department of Jewelry Engineering \\ Istanbul Commerce University \\ 34840 Istanbul, Turkey \\ ${ }^{2}$ Department of Chemistry, Sakarya University \\ 54100 Sakarya, Turkey
}

*to whom all correspondence should be addressed: e-mail: osaltabas@iticu.edu.tr

\begin{abstract}
Water hyacinth Eichhornia crassipes was found to have biosorption capacity for cationic dyes, malachite green and methylene blue from aqueous solutions. To evaluate the biosorption capacity and characteristics, the effect of solution $\mathrm{pH}$, initial dye concentration, temperature, dose of biosorbent loading, contact time and shaking rate were investigated in a batch mode. Biosorption was increased with the increasing temperature for both studied dyes. The Langmuir and Freundlich adsorption models were used for mathematical description of the sorption equilibrium. Equilibrium data was fitted well to the Langmuir model in the studied concentrations (1-200 $\left.\mathrm{mg} \mathrm{L}^{-1}\right)$ at 293 and $313 \mathrm{~K}$. Based on the Langmuir isotherm plots the maximum biosorption capacity values were calculated to be $44.64 \mathrm{mg} \mathrm{g}^{-1}$ for malachite green and $42.55 \mathrm{mg} \mathrm{g}^{-1}$ for methylene blue at $313 \mathrm{~K}$. Various thermodynamic parameters such as $\Delta \mathrm{G}^{\circ}, \Delta \mathrm{H}^{\circ}$, and $\Delta \mathrm{S}^{\circ}$ were evaluated with results indicating that this system was an endothermic spontaneous reaction and kinetically suited to pseudo-second-order model.
\end{abstract}

KEYWORDS: dye, malachite green, methylene blue, decolorisation, biosorption, adsorption isotherms, Water hyacinth roots.

\section{INTRODUCTION}

Synthetic dye stuffs are used extensively in industries such as textiles, leather, paper, plastic, etc. to color their final product. The extensive use of dye often poses pollution problems in the form of colored wastewater discharged into water bodies. However, colored dye effluents are known to be very toxic to aquatic life. They reduce the photosynthetic activity and primary production.

Physico-chemical processes such as electro-coagulation, ozonation, photocatalysis, membrane filtration and adsorption have been employed for the treatment of dye containing wastewater (Capar et al., 2006; Shu, 2006; Silva et al., 2006; Alinsafi et al., 2005). Among these technologies, adsorption process is considered to be a promising technology which involves phase transfer of dye molecules onto adsorbent leaving behind the clear effluent. Activated carbon is the most popular and widely used adsorbent for the removal of color from textile effluents but it is not used on a large scale due to its high cost, problems in regeneration or disposal of the used carbon. Recently, there has been a considerable amount of research to find cheaper alternatives to activated carbon. Recent progress in dye treatment technology has led to the development of new approaches utilizing lowcost, renewable, locally available biological or agricultural materials. Some of the adsorbent materials have already been used in dye sorption. These were activated clay (Özdemir et al., 2006; Weng and Pan, 2007), wheat bran (Sulak et al., 2007), fungal biomass ( Aksu and Çağatay, 2006; lqbal and Saeed, 2007), granular kohlrobi peel (Gong et al., 2007), macro alga (Marungrueng and Pavasant, 2006), brown seaweed (Vijayaraghavan and Yun, 2008), rice husk (Ponnusami et al., 
2007), fermentation wastes (Vijayaraghavan and Yun, 2007; Won and Yun, 2008) and yeast (Kumari and Abraham, 2007).

Water hyacinth has been used for removal of nutrients, heavy metals, organic compounds or pathogens from water. It is demonstrated that Water hyacinth roots have the high metal binding capacity (Saltabaş et al., 2001). Water hyacinth roots were used in basic dye biosorption (Low et al., 1995). However research on biosorption capacity of this biomass to remove dye from effluent is relatively limited.

In this study, biosorption of malachite green (MG) and methylene blue (MB), commonly used in textile industry for coloring clothes, onto dried Eichhornia crassipess roots biomass was investigated.

\section{MATERIALS AND METHODS}

\subsection{Preparation of the biosorbent}

Water hyacinth was collected from the Botanic garden of Istanbul University. The roots of collected Water hyacinth were separated and washed thoroughly with tap water for several times to remove earthy matter and all the particles. It was finally washed with distilled water three times and dried in an oven at a temperature of $80^{\circ} \mathrm{C}$ for 48 hours. Dry biomass was crushed into granules, sieved to different particle sizes and then preserved in a desiccator for subsequent uses. The particles less than $300 \mu \mathrm{m}$ were used in the experiments.

\subsection{Preparation of cationic dye solutions}

All chemicals used in this study were analytical grade. Malachite green (molecular weight: $329.46 \mathrm{~g}$ $\mathrm{mol}^{-1}, \lambda_{\max }: 617.3$ ) and methylene blue (molecular weight: $319.85 \mathrm{~g} \mathrm{~mol}^{-1}, \lambda_{\max }: 664.8$ ) were obtained from Merck AG and used without purifications. The dye stock solutions were prepared by dissolving accurately weighted dyes in distilled water to the concentration of $1000 \mathrm{mg} \mathrm{L}^{-1}$. The experimental solutions were obtained by diluting the dye stock solutions in different concentrations.

\subsection{Experimental procedure}

Biosorption studies were carried out by the batch technique to obtain equilibrium data. The initial $\mathrm{pH}$ values of the solutions were adjusted with solutions of $0.1 \mathrm{M} \mathrm{HNO}_{3}$ or $0.1 \mathrm{M} \mathrm{NaOH}$ before mixing the biomass suspension. The biosorption capacity of Water hyacinth roots was determined by contacting $100 \mathrm{~mL}$ of dye solutions of known concentration with certain amount of biosorbent in $250 \mathrm{~mL}$ flasks. The biosorbent in dye solution was shaken on an orbital shaker and removed from dye solution by centrifugation at $4500 \mathrm{rpm}$ for 5 minutes. The concentration of unadsorbed cationic dyes in the biosorption medium was measured colourimetrically using a spectrophotometer (UV-2410PC, Shimadsu, Kyoto, Japan). Blanks containing dye but no biosorbent were used for each series of experiments. The sorption experiments were carried out at 20 and $40{ }^{\circ} \mathrm{C}$ to determine the effect of temperature and to evaluate the thermodynamic parameters. All the experiments were carried out in duplicate and the results reported are the mean values from two separate measurements.

\subsection{Adsorption model}

The adsorption isotherm indicates how the adsorbate molecules distribute between the liquid and solid phase when the adsorption process reaches an equilibrium state. The Langmuir and Freundlich isotherm equations are usually employed for the liquid-solid systems.

The Langmuir theory assumes that sorption takes places at specific sites within the adsorbent. This means that once a molecule occupies a site, no further adsorption can take place at that site. Therefore, at equilibrium, a saturation point is reached beyond which no further adsorption can occur. The Freundlich model assumes that the sorption takes place on heterogeneous surfaces and adsorption capacity depends on the concentration of molecules at equilibrium.

The equilibrium data obtained for biosorption of MG and MB onto Water hyacinth roots biomass was analyzed using linearized Langmuir (Langmuir, 1918) and Freundlich (Freundlich, 1906) isotherms (Eqs. (1) and (2), respectively).

$C_{e} / q_{e}=1 / Q_{m} b+C_{e} / Q_{m}$

$\ln \left(\mathrm{q}_{\mathrm{e}}\right)=\ln \mathrm{k}_{\mathrm{F}}+1 / \mathrm{n}\left(\mathrm{C}_{\mathrm{e}}\right)$ 
where $C_{e}\left(\mathrm{mg} \mathrm{L}^{-1}\right)$ is the concentration of dye solution at equilibrium, $\mathrm{q}_{\mathrm{e}}\left(\mathrm{mg} \mathrm{g}^{-1}\right)$ is the amount of dye adsorbed at equilibrium, $Q_{m}\left(\mathrm{mg} \mathrm{g}^{-1}\right)$ is the maximum biosorption capacity. It represents a practical limiting adsorption capacity when the sorbent surface is fully covered with monolayer sorbate ions and $b\left(\mathrm{mg}^{-1}\right)$ is the adsorption constant related to the free energy of adsorption. The $Q_{m}$ and $b$ values were calculated from the slopes $\left(1 / Q_{m}\right)$ and intercepts $\left(1 / b Q_{m}\right)$ of linear plots of $C_{e} / q_{e}$ versus $\mathrm{C}_{\mathrm{e}} \cdot 1 / \mathrm{n}$ and $\mathrm{k}_{\mathrm{F}}\left(\mathrm{mg} \mathrm{g}^{-1}\right)$ are empirical Freundlich constants and indicate adsorption capacity and intensity, respectively. Their values were obtained from the intercepts $\left(\operatorname{lnk}_{F}\right)$ and slopes $(1 / n)$ of linear plots of Inq $_{e}$ versus $\operatorname{lnC}_{e}$.

\subsection{Kinetic modeling}

In order to investigate the controlling mechanism of biosorption process such as mass transport and chemical reaction processes, the pseudo-first order and pseudo-second order kinetic models are expressed as (Lagergren, 1898):

$\ln \left(q_{e}-q_{t}\right)=\ln q_{e}-k_{1} t$

where $k_{1}$ is the pseudo first order rate constant $\left(\mathrm{min}^{-1}\right)$ of adsorption and $q_{e}$ and $q_{t}\left(\mathrm{mg} \mathrm{g}^{-1}\right)$ are the amounts of dye molecules adsorbed at equilibrium and time $t$ (min.), respectively. The pseudo-firstorder considers the rate of occupation of adsorption sites to be proportional to the number of unoccupied sites. A straight line of $\ln \left(q_{e}-q_{t}\right)$ versus $t$ indicates the application of the first-order kinetics model. In a true first-order process $\ln q_{e}$ should be equal to the intercept of a plot of $\ln \left(q_{e}\right.$ $\mathrm{q}_{\mathrm{t}}$ ) against $\mathrm{t}$.

In addition, a pseudo-second-order equation (Ho and Mckay, 1998) based on adsorption equilibrium capacity may be expressed in the form:

$t / q_{t}=1 /\left[k_{2}\left(q_{e}\right)^{2}\right]+\left(1 / q_{e}\right) t$

where $\mathrm{k}_{2}\left(\mathrm{~g} \mathrm{mg}^{-1} \mathrm{~min}^{-1}\right)$ is the second-order reaction rate equilibrium constant. A plot of $\mathrm{t} / \mathrm{q}_{\mathrm{t}}$ against $\mathrm{t}$ should give a linear relationship for the applicability of the second-order kinetic.

\subsection{Thermodynamic parameters of biosorption}

In environmental engineering practice, both energy and entropy factors must be considered in order to determine which process will occur spontaneously. The Gibbs free energy change, $\Delta \mathrm{G}^{\circ}$, is the fundamental criterion of spontaneity. Reactions occur spontaneously at a given temperature if $\Delta G^{\circ}$ is a negative quantity. The Langmuir coefficient $b\left(\mathrm{mg}^{-1}\right)$ was used to calculate the Standard Gibbs free energy change $\left(\Delta G^{\circ}\right)$ according to the following equation:

$\Delta G^{\circ}=-R T \operatorname{lnb}$

where $\mathrm{R}$ is the universal gas constant $\left(8.314 \mathrm{~J} \mathrm{~mol}^{-1} \mathrm{~K}^{-1}\right), \mathrm{b}$, the Langmuir constant and $\mathrm{T}$ is the absolute temperature $(K)$. Change in free energy $\left(\Delta G^{\circ}\right)$, enthalpy $\left(\Delta H^{\circ}\right)$ and entropy $\left(\Delta S^{\circ}\right)$ for the adsorption process were calculated using the Eqs. (3)-(5) (Rajgopal et al., 2006).

$\ln \left(\mathrm{b}_{2} / \mathrm{b}_{1}\right)=-\Delta \mathrm{H}^{\mathrm{o}} / \mathrm{R}\left(1 / \mathrm{T}_{2}-1 / \mathrm{T}_{1}\right)$

$\Delta G^{\circ}=\Delta H^{\circ}-T \Delta S^{\circ}$

where, $b_{1}$ and $b_{2}$ are Langmuir constants at temperatures $T_{1}$ and $T_{2}$, respectively.

\section{RESULTS AND DISCUSSIONS}

\subsection{Effect of pH on dye uptake}

The $\mathrm{pH}$ of the aqueous solution is one of the important controlling parameters in the biosorption process. The variations in the biosorption of $\mathrm{MB}$ and MG dye were studied within the $\mathrm{pH}$ range 1-12. The results for this range are given in Figure 1. 


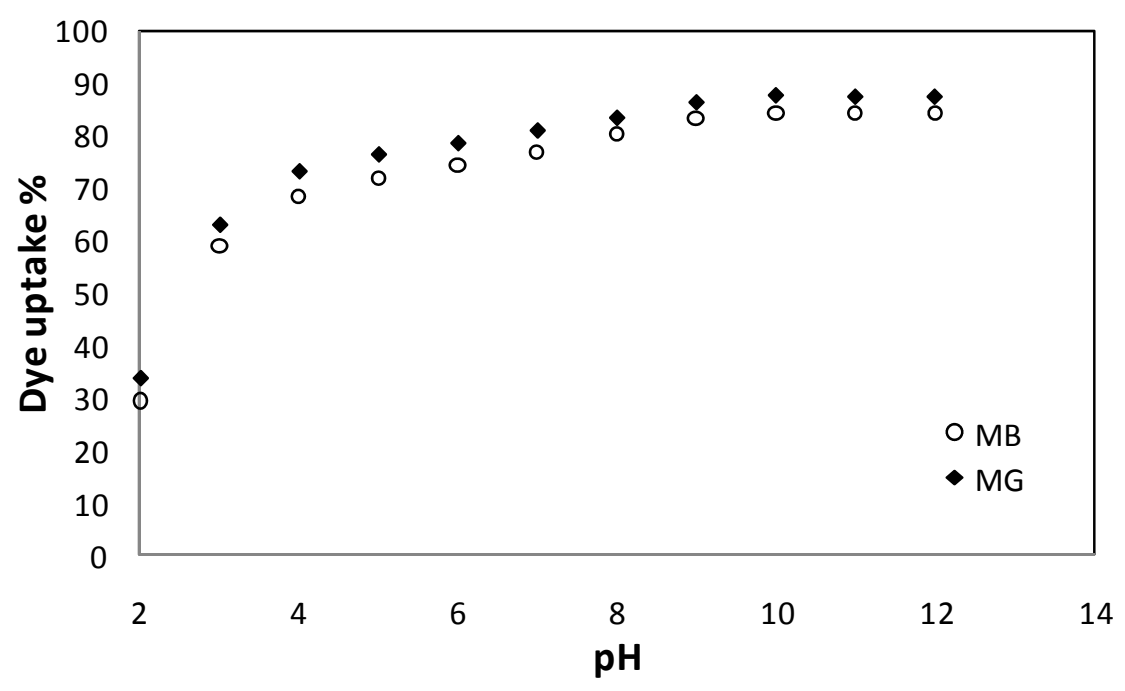

Figure 1. Effect of $\mathrm{pH}$ on the biosorption capacities of water hyacinth roots

(weight of biosorbent: $100 \mathrm{mg}$ of biosorbent per $100 \mathrm{~mL}$, initial dye concentration: $3 \mathrm{mg} \mathrm{L}^{-1}$, contact time: 60 min., temperature: $20^{\circ} \mathrm{C}$, shaking rate: $150 \mathrm{rpm}$ )

As seen in the Fig. 1, the uptake of $M G$ and $M B$ exhibits the maximum value at $\mathrm{pH}$ 9.5. Therefore, $\mathrm{pH} 9.5$ was used in the subsequent experiments for both MG and MB.

\subsection{Effect of contact time on dye uptake}

Fig. 2 indicates the MG and MB dye uptake as a function of contact time at temperature of $20{ }^{\circ} \mathrm{C}$. Figure 2 shows that the rate of dye uptake by water hyacinth roots is quite rapid. Maximum uptake occurred in the first 10 minute amounting to over $94.92 \%$ for MG and $91.75 \%$ for MB. This rapid rate of cationic dye uptake by Water hyacinth roots has a significant importance for applications in small reactor volumes. Thus it gives economical and effective advantages.

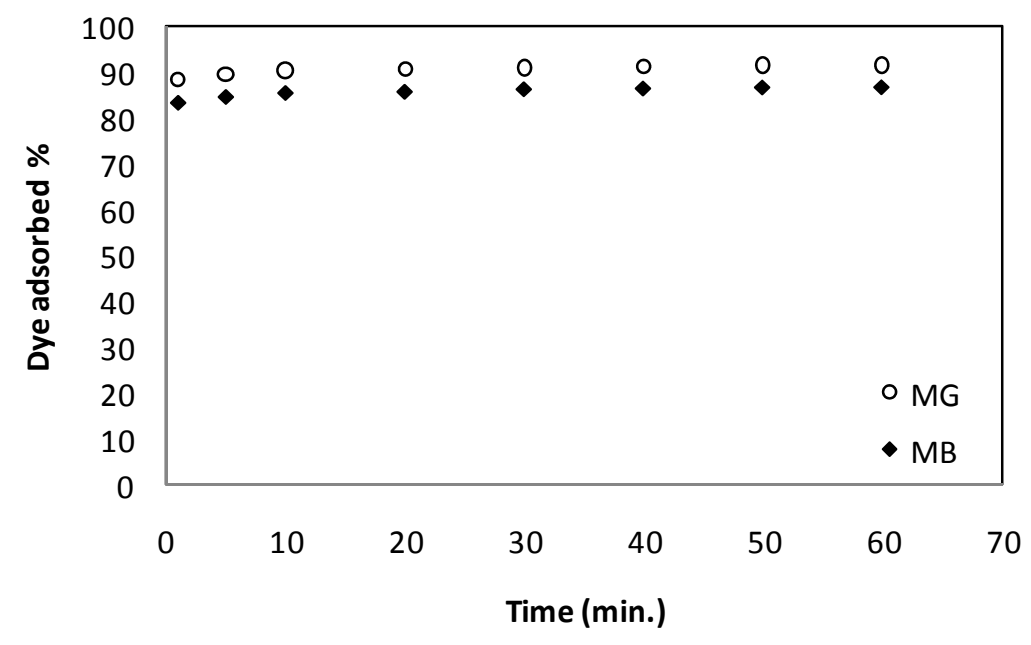

Figure 2. Effect of contact time on dye uptake (weight of biosorbent: $100 \mathrm{mg}$ of per $100 \mathrm{~mL}$, initial dye concentration: $2 \mathrm{mg} \mathrm{L}^{-1}, \mathrm{pH}: 9.5$, temperature: $20^{\circ} \mathrm{C}$, shaking rate: $150 \mathrm{rpm}$ )

\subsection{Adsorption kinetics modeling}

In order to analyze the adsorption kinetics of metals, the pseudo-first-order and pseudo-secondorder kinetic models were applied to data. The pseudo-second-order model was perfectly fitted to the experimental data. The comparison of experimental biosorption capacities and the theoretical values estimated from the above two models are presented in Table 1. The theoretical $\mathrm{q}_{\mathrm{e}}$ values estimated from the first-order kinetic model gave significantly different values than those of the experimental values, and the correlation coefficients were also found to be lower. These results 
indicate that the first-order kinetic model does not describe adsorption of MG and MB by Water hyacinth roots. The correlation coefficients for the linear plots of $t / q_{t}$ against $t$ for the second-order equation are 1 for both dyes for contact time of $60 \mathrm{~min}$. The theoretical $\mathrm{q}_{\mathrm{e}}$ values of MG and MB were very close to the experimental $q_{e}$ values in the case of second-order kinetics.

Table 1. Theoretically determined constants of pseudo-first and second-order reaction kinetics based on biosorption of MG and MB from $5 \mathrm{mg} \mathrm{L}^{-1}$ dye solutions by $100 \mathrm{mg}$ biosorbent per $100 \mathrm{~mL}$ at $\mathrm{pH} 9.5$ for $60 \mathrm{~min}$

\begin{tabular}{cccccccc}
\hline Dye & $\begin{array}{c}\text { Experimental } \\
\mathrm{q}_{\mathrm{e}} \\
\left(\mathrm{mg} \mathrm{g}^{-1}\right)\end{array}$ & \multicolumn{3}{c}{ Pseudo-first-order } & \multicolumn{3}{c}{ Pseudo-second-order } \\
\cline { 3 - 7 } & 22.549 & $\begin{array}{c}\mathrm{k}_{1} \\
\left(\mathrm{~min}^{-1}\right)\end{array}$ & $\begin{array}{c}\mathrm{q}_{\mathrm{e}} \\
\left(\mathrm{mg} \mathrm{g}^{-1}\right)\end{array}$ & $\mathrm{R}^{2}$ & $\begin{array}{c}\mathrm{k}_{2} \\
\left(\mathrm{~g} \mathrm{mg}^{-1} \mathrm{~min}^{-1}\right)\end{array}$ & $\begin{array}{c}\mathrm{q}_{\mathrm{e}} \\
\left(\mathrm{mg} \mathrm{g}^{-1}\right)\end{array}$ & $\mathrm{R}^{2}$ \\
\hline MG & 0.0859 & 0.713 & 0.9187 & 1.68 & 4.59 & 1 \\
MB & 22.469 & 0.0814 & 0.703 & 0.9595 & 1.50 & 4.35 & 1 \\
\hline
\end{tabular}

\subsection{Effect of biosorbent dosage on dye uptake}

Dye removal percentage versus the adsorbent dosage at $293 \mathrm{~K}$ is shown in Figure 3 . The dye uptake percent increased as the adsorbent quantity increased. However the biosorbed dye concentration was decreased from 18.97 to $0.27 \mathrm{mg} \mathrm{g}^{-1}$ biomass for MG and from 18.00 to $0.26 \mathrm{mg}$ $\mathrm{g}^{-1}$ biomass for $\mathrm{MB}$ with increasing in biosorbent concentration, from 0.01 to $1.0 \mathrm{~g} / 100 \mathrm{~mL}$. The decrease in biosorption capacity with increasing biosorbent concentration could be explained by not only unsaturation of biosorption sites through the adsorption reaction but also the particle interaction such as aggregation occurring at high biosorbent concentration and leading to decrease in total surface area.

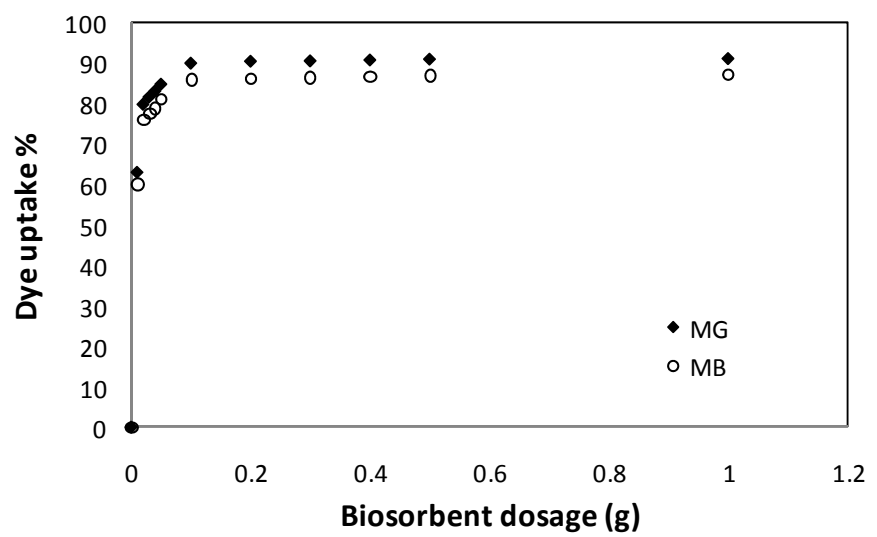

Figure 3. Effect of biosorbent dosage on dye uptake uptake (initial dye concentration: $3 \mathrm{mg} \mathrm{L}^{-1}$, $\mathrm{pH}: 9.5$, temperature: $20^{\circ} \mathrm{C}$, contact time: 60 min., shaking rate: $150 \mathrm{rpm}$ )

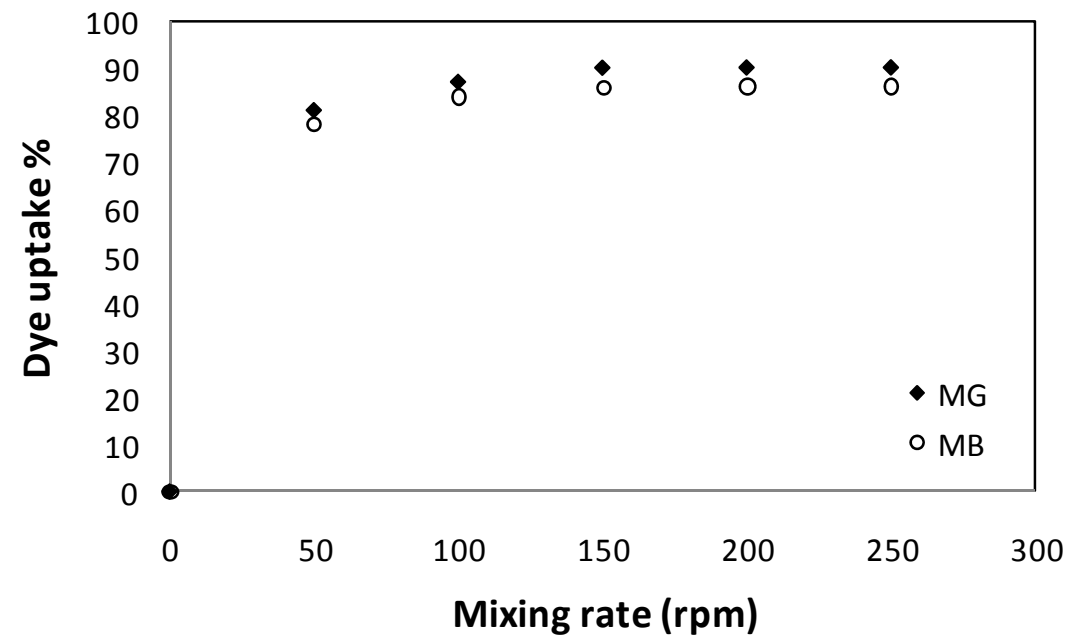

Figure 4. Effect of mixing rate on dye uptake (initial dye concentration: $3 \mathrm{mg} \mathrm{L}^{-1}, \mathrm{pH}: 9.5$, weight of biosorbent: $100 \mathrm{mg}$ of biosorbent per $100 \mathrm{~mL}$, temperature: $20^{\circ} \mathrm{C}$, contact time: $60 \mathrm{~min}$.) 


\subsection{Effect of mixing rate on dye uptake}

As shown in Figure 4, the dye uptake was found to increase with an increase in mixing rate. It is because the increase of mixing rate improves the diffusion of dye molecules to the surface of the adsorbent. It is found that $150 \mathrm{rpm}$ mixing rates were sufficient to assure the surface binding for both dye uptakes.

\subsection{Effect of initial dye concentration and temperature on dye uptake}

The equilibrium sorption capacity of the biomass increased as the initial MG and $M B$ dye concentration increased, while the adsorption yield of dye showed the opposite trend. The temperature also influenced remarkably the equilibrium dye uptake. With the change in temperature from 293 to $313 \mathrm{~K}$, the uptake capacity increased from 23.80 to $43.96 \mathrm{mg} \mathrm{g}^{-1}$ and from 22.02 to $41.56 \mathrm{mg} \mathrm{g}^{-1}$ at $200 \mathrm{mg} \mathrm{L}^{-1}$ initial MG and MB dye concentrations.

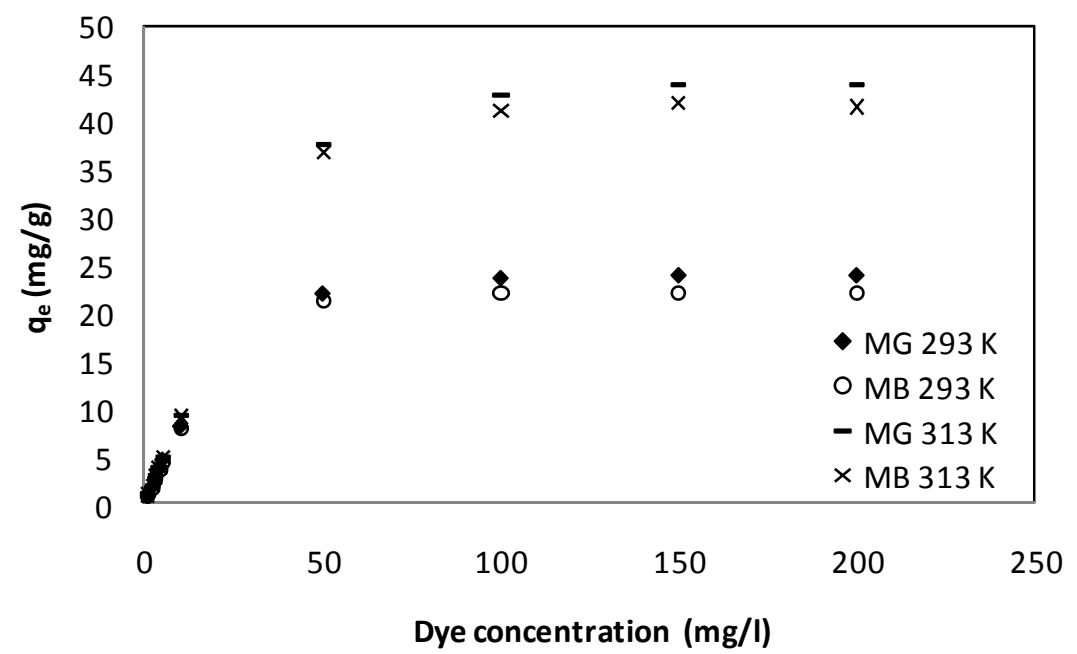

Figure 5. Effect of initial dye concentration on dye uptake at 293 and $313 \mathrm{~K}(\mathrm{pH}: 9.5$, weight of biosorbent: $100 \mathrm{mg}$ of biosorbent per $100 \mathrm{~mL}$, shaking rate: $150 \mathrm{rpm}$, contact time: $60 \mathrm{~min}$.)

\subsection{Adsorption isotherm}

With the data in Figure 5, the Langmuir and Freundlich equations were employed to study the sorption isotherms of dyes. The maximum adsorption capacity $\left(Q_{m}\right)$ and Langmuir constant $(b)$ were calculated from the plot between $\mathrm{C}_{\mathrm{e}}$ and $\mathrm{C}_{\mathrm{e}} / \mathrm{q}_{\mathrm{e}}$, the results were summarized in Table 2.

Table 2. Langmuir and Freundlich isotherm constants for the biosorption of MG and MB dye onto Water hyacinth roots at varying temperatures

\begin{tabular}{cccccccc}
\hline \multirow{2}{*}{ Dye } & $\begin{array}{c}\text { Biosorption } \\
\text { temperature }\end{array}$ & \multicolumn{3}{c}{ Langmuir constants } & \multicolumn{3}{c}{ Freundlich constants } \\
\cline { 3 - 7 } & $(\mathrm{K})$ & $\begin{array}{c}\mathrm{Q}_{\mathrm{m}} \\
\left(\mathrm{mg} \mathrm{g}^{-1}\right)\end{array}$ & $\begin{array}{c}\mathrm{b} \times 10^{-3} \\
\left(\mathrm{I} \mathrm{mg}^{-1}\right)\end{array}$ & $\mathrm{R}^{2}$ & $\mathrm{k}_{\mathrm{F}}$ & $1 / \mathrm{n}$ & $\mathrm{R}^{2}$ \\
\hline Malachite & 293 & 24.27 & 0.34 & 0.9998 & 4.05 & 0.4042 & 0.8864 \\
green & 313 & 44.64 & 0.43 & 0.9998 & 6.92 & 0.4416 & 0.9028 \\
\cline { 1 - 5 } Metylene & 293 & 22.57 & 0.30 & 0.9997 & 4.66 & 0.4028 & 0.8742 \\
blue & 313 & 42.55 & 0.42 & 0.9997 & 5.73 & 0.5133 & 0.9266 \\
\hline
\end{tabular}

Table 3. Thermodynamic parameters for the biosorption of MG and MB dye onto Water hyacinth roots as a function of temperature

\begin{tabular}{ccccccc}
\hline $\begin{array}{c}\text { Biosorption } \\
\text { temperature } \\
(\mathrm{K})\end{array}$ & \multicolumn{3}{c}{ Malachite green } & \multicolumn{3}{c}{ Methylene blue } \\
\cline { 2 - 6 } & $\begin{array}{c}\Delta \mathrm{H}^{\circ} \\
\left.\mathrm{kJ} \mathrm{mol}^{-1}\right)\end{array}$ & $\begin{array}{c}\Delta \mathrm{G}^{\circ} \\
\left(\mathrm{kJ} \mathrm{mol}^{-1}\right)\end{array}$ & $\begin{array}{c}\Delta \mathrm{S}^{\circ} \\
\left(\mathrm{J} \mathrm{mol}^{-1} \mathrm{~K}^{-1}\right)\end{array}$ & $\begin{array}{c}\Delta \mathrm{H}^{\circ} \\
\left(\mathrm{kJ} \mathrm{mol}^{-1}\right)\end{array}$ & $\begin{array}{c}\Delta \mathrm{G}^{\circ} \\
\left(\mathrm{kJ} \mathrm{mol}^{-1}\right)\end{array}$ & $\begin{array}{c}\Delta \mathrm{S}^{\circ} \\
\left(\mathrm{J} \mathrm{mol}^{-1} \mathrm{~K}^{-1}\right)\end{array}$ \\
\hline 293 & 9.35 & -28.32 & 128.57 & 12.57 & -27.93 & 138.25 \\
313 & 9.35 & -30.89 & 128.57 & 12.57 & -30.70 & 138.25 \\
\hline
\end{tabular}


In view of the values of linear regression coefficients in the Table 2, the Langmuir model exhibited better fit to the biosorption data of dye than the Freundlich model in the studied concentration and temperature ranges. The isotherm constants $Q_{m}$ were increased with increasing temperature.

As shown in Table 3, negative values of $\Delta G^{\circ}$ indicated that the biosorption process was favorable and spontaneous in nature for both $M G$ and $M B$. It may be noted that with the increase in temperature from 20 to $40{ }^{\circ} \mathrm{C}$, the value of $\Delta \mathrm{G}^{\circ}$ decreased from $-28.32 \mathrm{~kJ} \mathrm{~mol}^{-1}$ to $-30.89 \mathrm{~kJ} \mathrm{~mol}^{-1}$ for $M G$ and from $-27.93 \mathrm{~kJ} \mathrm{~mol}^{-1}$ to $-30.70 \mathrm{~kJ} \mathrm{~mol}^{-1}$ for MB. Thus biosorption of MG and MB dyes onto Water hyacinth roots biomass was enhanced at higher temperature. High temperatures increased the kinetic energy of the dye and, hence, enhanced the mobility of the dye ions. This led to a higher chance of the dye being adsorbed onto the adsorbent and an increase in its adsorption capacity. The positive value of enthalpy chance $\left(\Delta \mathrm{H}^{\circ}\right)$ confirmed the endothermic nature of the biosorption process. Positive values $\Delta S^{\circ}$ suggested good affinity of the dye towards the adsorbent. The same trend was reported by Patel and Suresh (2008).

\section{CONCLUSIONS}

This study confirmed that the biosorbent prepared from Water hyacinth roots, a low cost, easily available and environmentally problematic plant, could effectively remove MG and MB dye from an aqueous solution. The results would be useful for the design wastewater treatment plants for removal of dye. The equilibrium data fitted well to the Langmuir model in the studied concentration range at all the temperatures studied. According to Langmuir model, the maximum biosorption capacity was found to be $45.05 \mathrm{mg} \mathrm{g}^{-1}$ for $M G$ and $52.08 \mathrm{mg} \mathrm{g}^{-1}$ for MB dye under optimum conditions. The batch experiments showed the importance of solution $\mathrm{pH}$ and temperature in the biosorption of MG and MB. The biosorption capacity is strongly dependent on the temperature and increases significantly with increase in the temperature from 20 to $40^{\circ} \mathrm{C}$. Thermodynamic parameters showed that the biosorption of the $M G$ and $M B$ dyes was endothermic in nature. Negative values of $\Delta G^{\circ}$ indicated that the biosorption process was favorable and spontaneous in nature. Positive values $\Delta S^{0}$ suggested good affinity of the dye towards the adsorbent. The biosorption processes followed the pseudo-second-order rate kinetics.

\section{REFERENCES}

Aksu Z. and Çağatay Ş.Ş., (2006), Investigation of Biosorption of Gemazol Turquise Blue-G reactive by dried Rhzopus arrhizus in batch and continuous systems, Separation and Purification Technology, 48, 24-35.

Alinsafi A., Khemis M., Pons M.N., Leclerc J.P., Yaacoubi A., Benhammou A. and Nejmeddine A., (2005), Electro-coagulation of reactive textile dyes and textile waste-water, Chem. Eng. Process, 44, 461470.

Capar G., Yetis U. and Yilmaz L., (2006), Membrane based strategies for the pretreatment of acid dye bath wastewaters, J. Hazardous Mater, 135, 423-430.

Freundlich H., (1906) Adsorption in solution, Z. Phys. Chem., 57, 385-470.

Gong R., Zhang X., Liu H., Sun Y. and Liu B., (2007), Uptake of cationic dyes from aque-ous solution by biosorption onto granular kohlrabi peel, Bioresource Technology, 98, 1319-1323.

Ho Y.S. and McKay G., (1998) Sorption of dye from aqueous solution by peat, Chem. Eng. J., 70, 115124.

Iqbal M. and Saeed A., (2007), Biosorption of reactive dye by loofa sponge-immobilized fungal biomass of Phanerochaete chrysosporium, Process Biochemistry, 42, 1160-1164.

Kumari K. and Abraham T. E., (2007), Biosorption of anionic textile dyes by nonviable biomass of fungi and yeast, Bioresource Technology, 98, 1704-1710.

Lagergren S., (1898), Zur theorie der sogenannten adsorption gelöster stoffe, Kungliga Svenska Vetenskapsakademiens. Handlingar, 24, 1-39.

Langmuir I., (1918), The adsorption of gases on plane surfaces of glass, mica and platinum, J. Am. Chem. Soc., 40, 1361-1368.

Low K. S., Lee C.K. and Tan K. K., (1995), Biosorption of basic dyes by water hyacinth roots, Bioresource Technology, 52, 79-83.

Marungrueng K. and Pavasant P., (2006), Removal of basic dye (Astrazon Blue FGRL) using macroalga Caulerpa lentillifera, Journal of Environmental Management, 78, 268-274. 
Özdemir Y., Doğan M. and Alkan M., (2006), Adsorption of cationic dyes from aqueous solutions by sepiolite, Microporous and Mesoporous Materials, 96, 419-427.

Patel R., Suresh S., (2008), Kinetic and equilibrium studies on the biosorption pf reactive black 5 dye by Aspergillus foetidus, Bioresource Technology, 99, 51-58.

Ponnusami V., Krithika V., Madhuram R. and Srivastava S.N., (2007), Biosorption of reac- tive dye using acid-treated rice husk: Factorial design analysis, Journal of Hazar-dous Materials, 142, 397-403.

Saltabaş Ö., Akçin G. and Afşar H., (2001), Investigation of heavy metal uptake mechanism by biomass of Water hyacinth roots, $1^{\text {st }}$ Black Sea Basin Conference on Analytical Chemistry, Ukraine, p81.

Shu H.Y., (2006), Degradation of dyehouse effluent containing C.I. Direct Blue 199 by processes of ozonation, $\mathrm{UV} / \mathrm{H}_{2} \mathrm{O}_{2}$ and in sequence of ozonation with $\mathrm{UV} / \mathrm{H}_{2} \mathrm{O}_{2}$, Journal of Hazardous Materials, 133, 92-98.

Silva C.G., Wang W. and Faria J.L., (2006), Photocatalytic and photochemical degradation of mono-, diand tri-azo dyes in aqueous solution under UV irradiation, J. Photochem. Photobiol. A: Chem. 181, 314-324.

Srivastava S.K., Tyagi R. and Pant N., (1989), Adsorption of heavy metal ions on carbonaceous material developed from the waste slurry generated in local fertili-zer, Water Research, 23 (9), 1161-1165.

Sulak M.T., Demirbas E. and Kobya M., (2007), Removal of astrazan yellow 7GL from aqueous solutions by adsorption onto wheat bran, Bioresource Technology, 98, 2590-2598.

Rajgopal S., Karthikeyan T., Kumar B.G.P. and Miranda L.R. (2006), Utilization of fluidized bed reactor for the production of adsorbents in Removal of malachite green, Chem. Eng. J., 116, 211-217.

Vijayaraghavan K. and Yun Y.S., (2008), Biosorption of C.I. Reactive Black 5 from aqueous solution usig acid-treated biomass of Brown seaweed Laminaria sp. Dyes and Pigments, 76, 726-732.

Vijayaraghavan K. and Yun Y.S., (2007), Utilization of fermentation waste (Corynebacte-rium glutamicum) for biosorption of Reactive Black 5 from aqueous solution, Journal of Hazardous Materials, 141, 4552.

Weng C.H. and Pan Y.F., (2007), Adsorption of cationic dye (methylene blue) onto spent activated clay, Journal of Hazardous Materials, 144(1), 335-362.

Won S.W. and Yun Y.S., (2008), Biosorptive removal of Reactive Yellow 2 using waste biomass from lysine fermentation process, Dyes and Pigments, 76, 502-507. 